\title{
The Implementation of the Multiliteracies Pedagogy in Teaching Sentence Constructions of English Through Argumentative Essays
}

\author{
Henny Merizawati \\ The State Islamic University of Sunan Ampel Surabaya \\ Surabaya, Indonesia \\ hennymerizawati@gmail.com
}

\begin{abstract}
Due to the students' low abilities and difficulties in understanding sentence constructions in English, a new pedagogical approach is required to better assist students to identify the English sentence formation. This study aims at finding out the effectiveness of the multiliteracies approach to teaching the sentence structure of English through argumentative essays. The data were collected from 32 third-year college students taking two Morphology-Syntax classes in the State Islamic Institute of Bengkulu (IAIN Bengkulu). The participants were non-random or purposive students in the class of $C$ and $D$ who obtained the final result of the final exam that was not more than 70. The participants were divided into two groups: the control group and the experimental group. Participants in the control group were taught by using the traditional literacy pedagogy; meanwhile, participants in the experimental group achieved the treatment of the use of the multiliteracies pedagogy. In this essay, the analysis method used the one-way Analysis of Variance (ANOVA). The results of the study showed that the Probability Value (P-Value) of the pre-test score of the English sentence structure was 0.940 , and the P-Value of the pre-test score of the argumentative essays was 0.909 , so the null hypothesis $(\mathrm{HO})$ of the two treatments was accepted, which means that there were no statistically significant difference of pre-test scores between the control group and the experimental group. Meanwhile, the P-Value of the post-test score of the sentence constructions was 0.000 and the P-Value of the post-test score of the essays was 0.020 ; so that the alternative hypothesis $(\mathrm{H} 1)$ was accepted, which means that there was a major difference of posttest scores between the control group and the experimental group. This study proves that the multiliteracies pedagogy obtains better results in comprehending the English sentence constructions towards argumentative essays. Consequently, this research provides strong evidence to promoting multiliteracies through the English language teaching.
\end{abstract}

Keywords: multiliteracies; sentence constructions of English; argumentative essays

\section{INTRODUCTION}

\section{A. Background of the Study}

[1] stated that the global economic challenges in the workplace affect on the development of the information and communication technology (ICT hereafter) and the literacy [1]. This transformation also influences the educational field due to the demands and the challenges of the global level of education. It will run well if the educational curriculum can assist students to have better knowledge, abilities in order to answer the labour market challenge.Although the Indonesian 2013 Curriculum is designed to solve the issue in which to prepare the Indonesians "who are productive, creative, innovative, and effective" [2] and have the capability to play a role in the "society, nation state, and world civilization" [2], problems such as the teachers' readiness are still faced regarding the implementation of the 2013 curriculum [2, 3].

In addition, the ICT and the literacy issues also occur in the English language teaching and learning. Reading and writing, which are categorized as the traditional literacy approach, are two out of four English skills that students have to master. According to [4], writing is the English skill that is essential in the English language because students not only need to understand the skill but also require "an intricate combination of neurological, physical, cognitive, and affective competencies [5]. Therefore, most English as a Foreign Language (EFL) students, including Indonesian students, face difficulties when learning writing skills [4, 6, 7]. Several language experts as cited in [6] argued that some reasons why writing is difficult especially for Indonesian EFL students are the lack of correct English grammar and vocabulary, writing skills, and previous knowledge of the topic of writing as well as different cultural background, different textual patterns, and the lack of knowledge about writing. Furthermore, [7] stated that the choice of inappropriate learning model causes the low student writing skills. On the other hand, [8] argued that English teachers also face challenges when teaching writing. According to [8], the internal factors that teachers face due to teaching writing are "linguistics competence, native language, interference, motivation, and reading habits of the learners;" meanwhile the external aspects are "the class condition, aids available for teaching writing and the availability of time". Another significant issue with respect to the writing teaching and learning is the ability to master the ICT [9]. In spite of that, writing skills are inseparable from the ability to constructing good grammatical English sentences. Several solutions that can be used to help students to write better grammatical English sentences are "teachers' and friends' feedback, the sufficient time to practice, and good concentration on grammatical aspects" [10].

Besides the difficulty of teaching and learning writing in the EFL context, the traditional literacy pedagogy is not enough to fulfill the globalization needs. A new pedagogical 
approach is required due to the development of ICT called the multiliteracies pedagogy.

This study is conducted based on the researcher's own experience when teaching the sentence formation of English in two Morphology-Syntax classes (Class C and D) in the odd semester in the State Islamic Institute of Bengkulu (IAIN Bengkulu) in 2018. Most students in those classes got bad scores. In the Class $\mathrm{C}$, students obtained final scores which were more than $70(24 \%), 60-70(30 \%), 50-60(16 \%)$, and less than $50(27.7 \%)$. Meanwhile, in the Class D, students achieved final scores which were up to $70(37.9 \%), 60-70(48.2 \%)$, and under $50(13.7 \%)$. It can be seen that more than $50 \%$ of students in those classes got scores which were not more than 70. This research then attempts to answer the challenge to improve students' scores in terms of sentence constructions through the novel teaching approach.

\section{B. Problem of the Study}

The problem statement is "Does the multiliteracies pedagogy influence the students' ability in constructing English sentences through argumentative essays?" The research question assists the study to answer the issue regarding learning the English sentence formation towards argumentative essays.

\section{Objective of the Study}

The purpose of the study is to demonstrate the effectiveness of the multiliteracies. Specifically, this study aims to identify the influence of the multiliteracies pedagogy to improve the students' ability in forming English sentences.

\section{Hypothesis}

This study tests the researcher's hypothesis. The null hypothesis (H0) is that there is no significant difference between the pre-test scores of the control group and the experimental group regarding learning the sentence constructions of English in argumentative essays. Meanwhile, the alternative hypothesis (H1) is that the post-test scores will be higher for the experimental group than the control group in terms of the students' ability in constructing English sentences in argumentative essays.

\section{E. Significance of the Study}

It is believed that this research will give positive impacts to the students' ability in comprehending the English sentences. Furthemore, this study aims to implement the multiliteracies pedagogy to improve the students' understanding of the English sentence structures towards argumentative essays. Moreover, this study will enrich the English language teaching approach.

\section{F. Scope and Limitation}

The scope of the study is the implementation of the multiliteracies pedagogy regarding the sentence constructions of English through argumentative essays. Meanwhile, The external validity, which is the generalizability, of this study will be limited because of the small sample size of the data, and the time when collecting the data is also restricted, so the researcher cannot practice various multiliteracies techniques.

\section{LITERATURE REVIEW}

According to $[11,12,13]$, some terms relate to the multiliteracies pedagogy as follow:

\section{A. Definition of Multiliteracies}

Multiliteracies is a creative, innovative, productive, effective, prolific, ingenious, and inventive pedagogical implementation in the classroom through the ongoing modes of learning in a new way to address the issues of local diversity, social engagement and globalization.

\section{B. Meaning-Making Process}

The meaning-making process is the process of how people analyze the situations and the events in their lives by using what they have learned and what they have experienced.

\section{Design Elements}

Six design elements in the meaning-making process are Linguistics meanings (delivery, vocabulary and metaphor, modality, transitivity, nominalization of process, information structures, local coherence relations, global coherence relations), Visual meanings (image, page layouts, screen formats, colors, perspective, vectors, foregrounding and backgrounding), Audio meanings (music, sound effects), Gestural meanings (body language, sensuality, behavior, bodily physicality, gesture, feelings and affect, kinesics, proxemics), Spatial meanings (the meanings of environmental spaces, architectural spaces, ecosystemic and geographic meanings), and Multimodal meanings.

\section{Multimodal}

The multimodal is the key element of modes of meaning because it reflects the combinations of other designs. It is all meaning-making.

\section{E. Metalanguage}

Metalanguage is a form of language, which is used to explain modes of meaning as well as the languages, images, texts, and meaning-making interactions.

\section{F. Designs}

Three concepts of designs are the Designs or Available Designs (multimodal resources for Designs), Designing (the process of transforming from available designs), and the redesigned (the product or the result or the outcome of Designing).

\section{G. Knowledge Processes}

Four knowledge processes are Experiencing (applying students' own experience about the topic), Conceptualizing (understanding and mastering the concepts), Analysing (exploring and analyzing the concept), and Applying (transforming the concepts into practices).

\section{H. Four Components of Multiliteracies}

Four components of Multiliteracies are Situated Practice (students and teachers use their own existing knowledge and experience by way of the use of multimodal resources), Overt Instruction (teachers directly teach the concepts by means of 
multimodal and technological resources), Critical Framing (students use their critical thinking in analyzing the concepts), and Transformed Practice (students transform their existing knowledge through the essays).

\section{Previous Studies}

Many studies regarding the multiliteracies pedagogy have been conducted in the form of dissertations and theses. [15] explored the multiliteracies pedagogy in a Malaysian Polytechnic classroom through a participatory action research project. Her findings showed that the students' examinationbased learning and cultural practices as well as multiliteracies could improve students' negotiation of learning $21^{\text {st }}$ century skills. In addition, [16] examined a lived story of a teacher performing the multiliteracies in the classroom. The results pointed that multiliteracies motivate teachers' selfdevelopment. Moreover, [17] reviewed the knowledge processes proposed by $[11,12]$ in three upper secondary school English textbooks, "ENA 3 Cultural Phenomena (LOPS2016), Insights Course 3, and On Track 3." The results were that the three textbooks did not show any significant difference in terms of the knowledge processes in the multiliteracies pedagogy.

Besides a dissertation and theses, the researcher also found some articles disscussing the multiliteracies. The main articles are $[11,12,13]$. They stated several terminologies with regards to the pedagogy of multiliteracies. Some of them are multimodal (linguistics meanings, visual meanings, audio meanings, gestural meanings, and spatial meanings), designs (the designs or available designs, designing, and the redesigned), the knowledge processes (experiencing, conceptualizing, analyzing, and applying), and the components of multiliteracies (situated practice, overt construction, critical framing and transformed practice). Meanwhile, [13] proposed the "why" of multiliteracies, the "what" of multiliteracies, and the "how" of multiliteracies. Furthermore, a lot of studies in the field of multiliteracies were analyzed. Some of them analyzed the writing skills. [17] studied the usefulness of multiliteracies in teaching in an ESL writing classroom. The findings showed that multimodal pedagogical practices improved students' outcomes. Not much different from [17], other research investigated the multiliteracies in the ESL writing and the result was that the multiliteracies pedagogy promoted the students' ability in writing creative essays [18]. On the other hand, [19] focused on constructing multimodal arguments in writing. Their findings indicated the Ipad-based assessment overcomes the reading difficulties of Kindergarten through the third-grade students. Furthermore, [20] used the digital writing in the English education to explore multiliteracies.

In addition to the dissertation and theses as well as articles with the qualitative method, the researcher also found several previous research using the quantitative method [7, 21]. [7] examined the effectiveness of the elementary school students' creative writing ability towards the multiliteracies. [21] studied the implementation of the multiliteracies pedagogy towards the elementary school students' reading ability.

In general, the researcher found out some previous studies discussing multiliteracies in the area of writing; however, a very small number of research noted the English sentence formation and used argumentative essays as the writing practice, and few studies used the quantitative method, particularly the quasi-experimental design.

\section{METHODOLOGY}

\section{A. Participants and Setting}

The participants were 32 third-year college students taking two Morphology-Syntax classes in the State Islamic Institute of Bengkulu (IAIN Bengkulu). These purposive participants were selected from the class $\mathrm{C}$ and $\mathrm{D}$ whose final scores were not more than 70 . They were divided into two groups: the control group and the experimental group. The control group consists of 16 participants; meanwhile, other 16 participants joined in the experimental group. The traditional literacy pedagogy was taught in the control group class; meanwhile, participants in the experimental group got the treatment of the use of the multiliteracies pedagogy.

\section{B. Instruments}

The instruments in this study were the writing tests coming from the pre-test and the post-test. Both the pre-test and the post-test were approximately 250 words. The pre-test was conducted at the first meeting, and the post-test was at the last meeting.The topic of the pre-test was the advantages and disadvantages of the internet; meanwhile, the post-test was about the effects of global warming. Participants should include 20 items of sentence constructions which were noun phrases, verb phrases, prepositional phrases, adjective phrases, adverbial phrases, independent clauses, dependent clauses, relative clauses, noun clauses, active sentences, passive sentences, WH-questions, adjuncts, recursions, complementizers, conjunctions, copulas, transitive verbs, and intransitive verbs. Moreover, the data had been collected for a month in February 2019. During their pre-test and post-test, students used the knowledge processes and four components of the multiliteracies pedagogy, and the researcher used the designs of multiliteracies.

\section{Research Methodology}

This study used the quantitative method following post positivist knowledge claims [22, 23]. In more detail, this research applied the quasi - experimental design in measuring the pre-test and the post-test. To describe the data analysis, the researcher used the descriptive statistics. In addition, variables used were the control variables which were the MorphologySyntax classes and participants, the independent variable which was the treatment, and the dependent variable which was the participants' ability in constructing the English sentences through argumentative essays.

\section{Procedures of Collecting the Data}

In this study, participants in the two groups conducted the pre-test which was an argumentative essay about advantages and disadvantages of the Internet at the first meeting. Then, specifically for the experimental group, the researcher applied the multiliteracies pedagogy. The researcher construed the concept of designs, which were available designs, designing, and redesigned [11, 12, 13]. Next, participants followed 
knowledge processes including experiencing, conceptualizing, analyzing and applying as well as four components of the multiliteracies pedagogy consisting of situated practice, overt construction, critical framing, and transformed practice [11, $12,13]$. What participants did was that participants explored what they knew about the English sentence structures. Next, the researcher used technological facilities such as images, video call with Whatsapp, and e-mail when teaching the sentence constructions and the essays. After that, participants should think critically in analyzing the sentence formation. Finally, they transferred their knowledge to the post-test which was the effects of global warming. The participants in the control group also conducted the post-test.

\section{E. Data Analysis}

Regarding the data analysis, the researcher used the descriptive method and the statistical method. Several statistics measured were means, standard deviations, and the Confidence Interval (CI). Furthermore, in order to answer the research question and to examine the null and alternative hypothesis, the researcher used the Analysis of Variance (ANOVA). Regarding the interpretation of findings, the researcher investigated whether the researcher's hypothesis is supported or rejected. Also, the researcher explored the treatment of the multiliteracies pedagogy to improve the participants' ability in constructing English sentences through argumentative essays. At last, the researcher indicated the implication of this study for future research.

\section{RESULTS AND DISCUSSION}

\section{A. Results}

The data analysis was conducted to find out the influence of multiliteracies pedagogy to improve the students' compentence in the English sentence formation towards argumentative essays. The researcher carried out a quantitative analysis, particularly the quasi-experimental design using descriptive - statistics. The Analysis of Variance (ANOVA) was employed to determine the Probability Value (the PValue), the null hypothesis (H0), and the alternative hypothesis (H1). In order to answer the research question, the researcher provides some Tables and Graphics. Table 1 shows a descriptive statistics of the Mean, Standard Deviation (SD), and Confidence Interval (CI) of the pre-test of sentence constructions, and Graphic 1 indicates an interval plot of the pre-test of sentence constructions.

TABLE 1. A DESCRIPTIVE STATISTICS OF THE MEAN, STANDARD DEVIATION (SD), AND CONFIDENCE INTERVAL (CI) OF THE PRE-TEST OF SENTENCE CONSTRUCTIONS

\section{Means}

$$
\begin{aligned}
& \text { Metode N Mean StDev } 95 \% \mathrm{Cl} \\
& \begin{array}{lllll}
\text { A } & 16 & 72.54 & 11.91 & (66.64,78.44)
\end{array}
\end{aligned}
$$

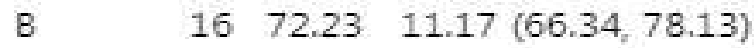

$$
\begin{aligned}
& \text { Pooled StDev }=11.5467
\end{aligned}
$$

NB: A = The Experimental Group; B = The Control Group
GRAPHIC 1. AN INTERVAL PLOT OF THE PRE-TEST OF SENTENCE CONSTRUCTIONS

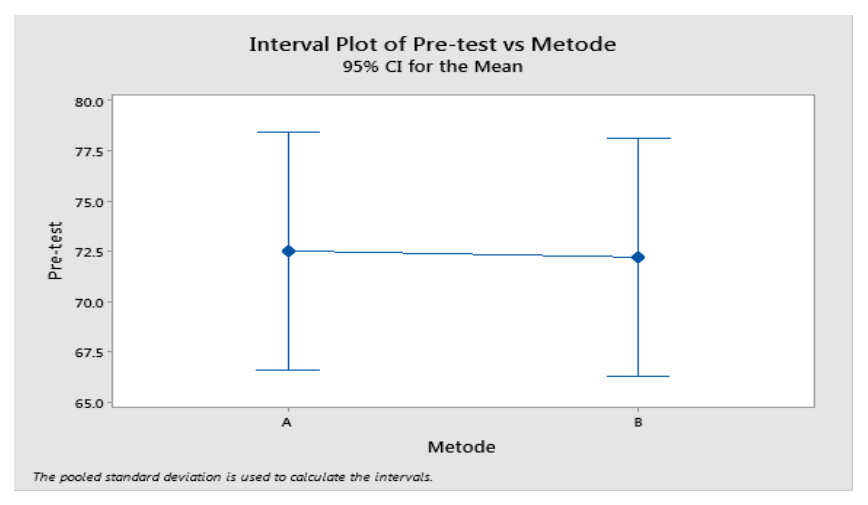

NB: A = The Experimental Group; B = The Control Group

As can be seen in Table 1 and Graphic 1, there was no significant difference of the mean and Standard Deviation between the experimental group and the control group with the Confidence Interval which was $95 \%$ for the Mean. It appears that students in both groups had the same ability in constructing English sentences before they became participants in this study. Then, Table 2 provides a descriptive statistics of the Probability-Value (P-Value) of the pre-test of sentence formations.

TABLE 2. A DESCRIPTIVE STATISTICS OF THE PROBABILITYVALUE (P-VALUE) OF THE PRE-TEST OF SENTENCE FORMATIONS.

\section{Analysis of Variance}

\begin{tabular}{lrrrrr} 
Source & DF & Adj SS & Adj MS & M-Value & P-Value \\
\hline Metode & 1 & 0.76 & 0.760 & 0.01 & 0.940 \\
Error & 30 & 3999.76 & 133.325 & & \\
Total & 31 & 4000.52 & & &
\end{tabular}

NB: Cumulative Factor $(\mathrm{CF})=0.05$

The P-Value of the pre-test of sentence constructions was above the Cumulative Factor (CF) (as shown in Table 2). It means that the Null Hypothesis (H0) was accepted. There is a strong possibility that there was no a major difference between the capability of participants in both groups during the pretest. Moreover, Table 3 plots a descriptive statistics of the post-test of sentence formations and Graphic 2 shows the interval plot of the post-test of sentence formations.

TABLE 3. A DESCRIPTIVE STATISTICS OF THE MEAN, STANDARD DEVIATION (SD), AND CONFIDENCE INTERVAL (CI) OF THE POST-TEST OF SENTENCE FORMATIONS

\section{Means}

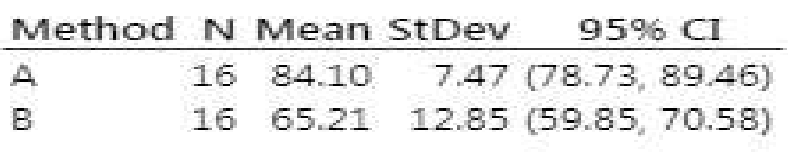

Pooled StDer $=10.5112$

NB: $\mathrm{A}=$ The Experimental Group; $\mathrm{B}=$ The Control Group 
GRAPHIC 2. THE INTERVAL PLOT OF THE POST-TEST OF SENTENCE FORMATIONS

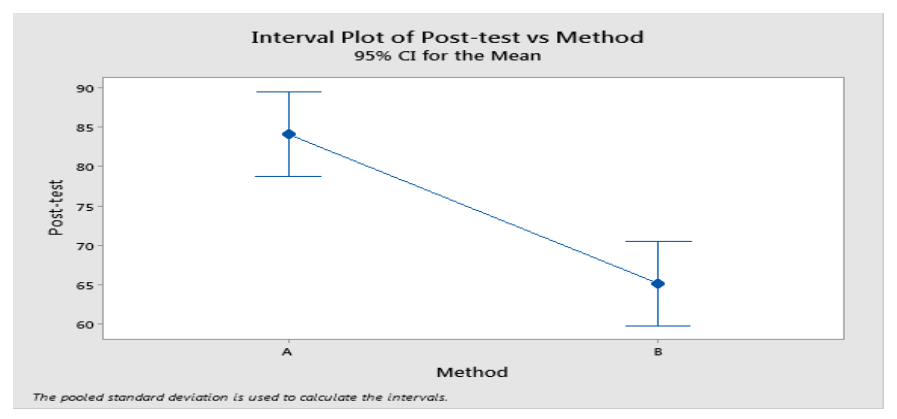

NB: A= The Experimental Group; $\mathrm{B}=$ The Control Group

The Mean and the Standard Deviation of the post-test of sentence formations which showed different results are provided in Table 3 and Graphic 2. It can be seen that the Mean of participants' scores in the experimental group was higher than the mean of participants' scores in the control group. Meanwhile, the Standard Deviation of the experimental group was lower than the Standard Deviation of the control group. It is certain that the multiliteracies pedagogy had a positive impact on the students' understanding of sentence formations. Next, Table 4 reveals a descriptive statistics of the Probability-Value (P-Value) of the post-test of sentence structures.

TABLE 4. A DESCRIPTIVE STATISTICS OF THE PROBABILITYVALUE (P-VALUE) OF THE POST-TEST OF SENTENCE STRUCTURES.

\section{Analysis of Variance}

\begin{tabular}{|c|c|c|c|c|c|}
\hline Method & 1 & 2852 & 2852.2 & 25.82 & 0.000 \\
\hline Error & 30 & 3315 & 110.5 & & \\
\hline Total & 31 & 6167 & & & \\
\hline
\end{tabular}

NB: Cumulative Factor $(\mathrm{CF})=0.05$

Table 4 indicates that the P-Value of the post-test of sentence structures was lower than the $\mathrm{CF}$, which means that the Alternative Hypothesis (H1) was accepted. It can be concluded that most participants in the experimental group obtained higher scores compared to participants' post-test scores in the control group. The results of the essays are presented below. Later, Table 5 plots a descriptive statistics of the Mean, Standard Deviation (SD), and Confidence Interval (CI) of the pre-test of argumentative essays, and Graphic 3 shows the interval plot of the pre-test of sentence constructions of argumentative essays.
TABLE 5. A DESCRIPTIVE STATISTICS OF THE MEAN, STANDARD DEVIATION (SD), AND CONFIDENCE INTERVAL (CI) OF THE PRE-TEST OF ARGUMENTATIVE ESSAYS

\section{Means}

\begin{tabular}{lrrrc} 
Method $N$ & Mean StDev & $95 \% \mathrm{CI}$ \\
\hline $\mathrm{A}$ & 16 & 52.19 & 16.53 & $(44.39,59.98)$ \\
$\mathrm{B}$ & 16 & 52.81 & 13.90 & $(45.02,60.61)$
\end{tabular}

Pooled StDer $=15.2718$

NB: $\mathrm{A}=$ The Experimental Group; $\mathrm{B}=$ The Control Group

GRAPHIC 3. THE INTERVAL PLOT OF THE PRE-TEST OF ARGUMENTATIVE ESSAYS

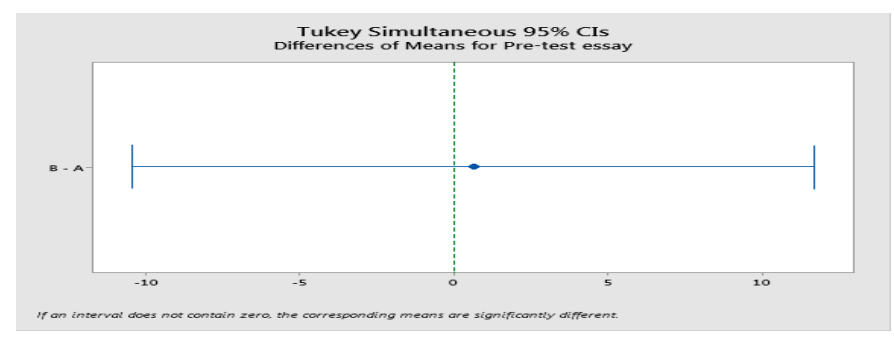

NB: $A=$ The Experimental Group; $B=$ The Control Group

The mean and the Standard Deviation of the pre-test of argumentative essays in the control group did not show any significant difference from those of the experimental group (see Table 5 and Graphic 3). It seems that the ability of the majority of participants in both groups in understanding the essays was equal before participants in the experimental group received the treatment of the multiliteracies pedagogy. In addition, Table 6 displays a descriptive statistics of the Probability-Value (P-Value) of the pre-test of argumentative essays.

TABLE 6. A DESCRIPTIVE STATISTICS OF THE PROBABILITYVALUE (P-VALUE) OF THE PRE-TEST OF ARGUMENTATIVE ESSAYS

\section{Analysis of Variance

\begin{tabular}{lrrrrr} 
Source & DF & Adj SS & Adj MS & F-Value & P-Value \\
\hline Method & 1 & 3.13 & 3.125 & 0.01 & 0.909 \\
Error & 30 & 6996.87 & 233.229 & & \\
Total & 31 & 7000.00 & & & \\
\hline
\end{tabular}

NB: Cumulative Factor $(\mathrm{CF})=0.05$

Alike the result of the P-Value in sentence structures, the $\mathrm{P}-\mathrm{Value}$ of the pre-test score in comprehending the essays was higher than the CF (as can be shown in Table 6). It means that HO was accepted, which can be concluded that there was no a great difference among participants in the two groups in understanding the essays. Furthermore, Table 7 presents a descriptive statistics of the post-test of argumentative essays and Graphic 4 indicates the interval plot of the post-test of argumentative essays. 
TABLE 7. A DESCRIPTIVE STATISTICS OF THE MEAN, STANDARD DEVIATION (SD), AND CONFIDENCE INTERVAL (CI) OF THE POST-TEST OF ARGUMENTATIVE ESSAYS

\section{Means}

\begin{tabular}{lllll}
\multicolumn{4}{c}{ Method N } & \multicolumn{4}{c}{ Mean StDev } & $95 \%$ Cl \\
\hline A & 16 & 71.88 & 9.11 & $(67.64,76.11)$ \\
B & 16 & 64.69 & 7.41 & $(60.45,68.93)$
\end{tabular}

Pooled StDer $=8,30098$

NB: $\mathrm{A}=$ The Experimental Group; $\mathrm{B}=$ The Control Group

GRAPHIC 4. THE INTERVAL PLOT OF THE POST-TEST OF ARGUMENTATIVE ESSAYS

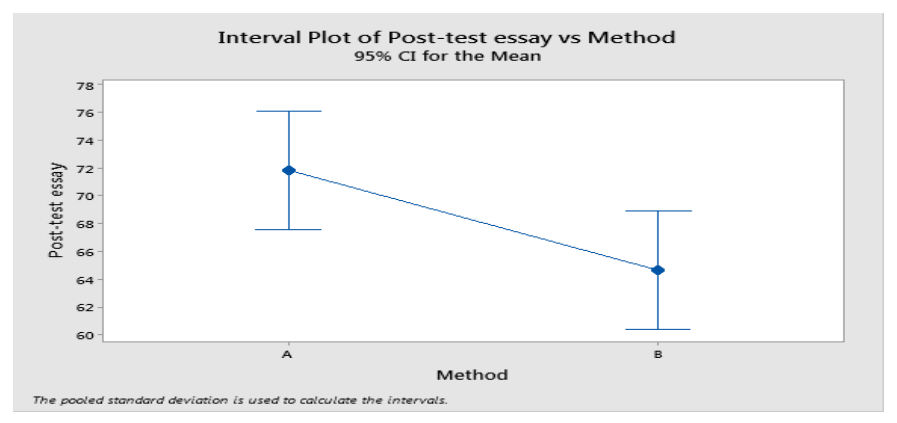

NB: A = The Experimental Group; B = The Control Group

From Table 7 and Graphic 4, it can be seen that the average and the data distribution of the post-test of the essays on the participants' ability in writing the essays tend to be the same. It seems that the participants' ability in the experimental group develops rapidly compared to the participants' skill in the control group. Finally, Table 8 shows a descriptive statistics of the Probability-Value (P-Value) of the post-test of argumentative essays.

TABLE 8. A DESCRIPTIVE STATISTICS OF THE PROBABILITYVALUE (P-VALUE) OF THE POST-TEST OF ARGUMENTATIVE ESSAYS

\section{Analysis of Variance}

\begin{tabular}{lrrrrr} 
Source & DF Adj SS Adj MS F-Value P-Value \\
\hline Method & 1 & 413.3 & 413.28 & 6.00 & 0.020 \\
Error & 30 & 2067.2 & 68.91 & & \\
Total & 31 & 2480.5 & & &
\end{tabular}

NB: Cumulative Factor $(\mathrm{CF})=0.05$

As shown in Table 8, the CF was lower than the P-Value, which means that $\mathrm{H} 1$ was accepted. It seems that participants in the experimental group obtained final scores which were higher than participants in the other group. Consequently, from the whole findings, this study has found that the multiliteracies pedagogy is strongly recommended in teaching and learning sentence constructions of English as well as the essays. The results in this research are similar to the researcher's initial hypothesis that the multiliteracies gives the positive influence in improving the students' ability in constructing the English sentence constructions towards the argumentative essays.

\section{B. Discussion}

As shown in the findings above, the ability of participants in the experimental group achieved the significant improvement compared to the participants' capabilities in the control group. It can be seen from the scores in the pre-test and the post-test as well as the mean and the Standard Deviation. The results of this study is similar to several previous studies' findings towards the influence and the effectiveness of the multiliteracies pedagogy. [7] investigated the ability of the creative writing; meanwhile [21] looked at the reading ability. Both [7] and [21] had the mean of the pretest in which there was no a significant difference between the experimental group and the control group. Furthermore, the post-test scores of participants in the experimental group increased substantially, which means that there was a positive influence of the use of multiliteracies as described in [7] and [21].

According to $[7,21,24,25,26,27,28]$, the main reason why the multiliteracies pedagogy gives positive impacts on the students' ability is due to the special treatment received by students in the multiliteracies classroom. Students applied the novel way of a pedagogical method called the multiliteracies. They should have the existing knowledge and experience of the study materials. Moreover, they are required to be active, critical, creative, and innovative as well as to collaborate and to communicate with the teachers and classmates. In addition, they should use various multimodal and technological resources, which means that they have to boost their understanding of the ICT. As a result, their positive mindset and learning motivation improve drastically that affect their scores.

Besides, [7, 21, 24, 25, 26, 27, 28] also stated that the multiliteracies pedagogy will not work well if there is no a good collaboration between students and teachers. The teachers play an important role for the success of the multiliteracies practices. The teachers should build the supportive and productive learning environment. They should also use some learning methods as well as multimodal resources, which means that they should be aware of the use of the ICT. Like students, the teachers should design creative ideas in teaching in order to bring out the talent and the interest of students. Therefore, they should become the learning designers and total professional teachers.

\section{CONCLUSION}

This research represents an attempt to implement the multiliteracies pedagogy in the field of teaching and learning sentence structures of English through argumentative essays. The results of this study indicate that the experimental group and the control group did not show any significant difference in terms of pre-test scores. However, there was a significant difference between the experimental group and the control group regarding the post-test scores. In conclusion, the 
capability of participants in the experimental group increases dramatically compared to the ability of participants in the control group. Consequently, this study brings out the important progress on the issues in teaching and learning writing skills of English.

In addition, further research can be conducted to examine the implementation of the multiliteracies pedagogy. The researcher recommends that future studies might have a larger sample size, which can make the data more valid and more reliable. The future research can also investigate other English skills in terms of implementing multiliteracies such as the reading skill. Moreover, further studies can look for the teachers' and students' perceptions towards multiliteracies.

\section{REFERENCES}

[1] M. Ganapathy, "The effect of incorporating multiliteracies pedagogy in ESL writing," International Journal of Arts and Sciences, vol. 08(06), pp.253-268, 2015.

[2] A. Jaedun, V.L. Hariyanto, and Nuryadin, "An evaluation of the implementation of curriculum 2013 at the building construction department of vocational high schools in Yogyakarta," Journal of Education, vol. 7 (1), pp. 14-22, November 2014.

[3] D. Ahmad, "Understanding the 2013 curriculum of English teaching through the teachers' and policymakers' perspectives," International Journal of Enhanced Research in Educational Development (IJERED), vol. 2(4), pp. 6-15, July-August 2014.

[4] Ariyani, "The teaching of EFL writing in Indonesia," Dinamika Ilmu, vol. 16(2), pp. 263-277, 2016.

[5] Murray and Moore, The handbook of academic writing. New York: Open University Press, 2006.

[6] I. H. Abas and N. H. A. Azis, "Indonesian EFL students' perspectives on writing process: a pilot study," Advances in Language and Literacy Studies, vol. 7(3), pp. 21-27, June 2016.

[7] F. Dafit, "Keefektifan kemampuan menulis kreatif siswa sekolah dasar dengan model pembelajaran multiliterasi," Gerakan Aktif Menulis (GERAM), vol. 5(1), pp. 49-57, June 2017.

[8] K. H. Hidayati, "Teaching writing to EFL learners: An investigation of challenges confronted by Indonesian teachers," Langkawi Journal (Journal of the Association for Arabic and English), vol. 4(1), pp. 21-31, 2018.

[9] P. Kusumawardhani and Nurhayati, "The analysis of teaching writing to English Young Learners (EYL) through a movie: An ICT perspective," Wanastra Jurnal Bahasa dan Sastra, vol. 11(1), pp. 25-34, March 2019.

[10] Y. C. G. Mali, "Writing grammatical sentences: Voices of Indonesian undergraduates in EFL classrooms," Jurnal Pendidikan Bahasa dan Sastra, vol. 16(1), pp. 14-22, April 2016.

[11] The New London Group, "A pedagogy of multiliteracies: Designing social futures," Harvard Educational Review, vol 66(1), pp. 60-92, 1996.

[12] The New London Group, A pedagogy of multiliteracies. In B. Cope \& M. Kalantzis (Eds). London: Routledge, 2000.
[13] B. Cope and M. Kalantzis, "Multiliteracies: New literacies, new learning," Pedagogies: An International Journal, vol. 4(3), pp. 164-195, 2009.

[14] F. Puteh-Behak, N. Massari, and H. Harun, "Learning with a sense of adventure through a multiliteracies approach in an examination-oriented learning context," Frontiers of Language and Teaching, vol. 6, pp. 4153, 2015.

[15] F. Puteh-Behak, Using a multiliteracies approach in a Malaysian Polytechnic classroom: A participatory action research project (Doctoral Thesis, University of Southern Queensland), 2013.

[16] X. Meng, A pedagogy of multiliteracies into practice: A case study in one grade one literacy classroom (Master's Thesis, Western University), 2016.

[17] E. Jarho. The knowledge processes framework and multiliteracies in upper secondary school English textbooks ENA 3 Cultural Phenomena (LOPS2016), insight course 3 and on track 3 (Master's Thesis, University of Tampere), 2017.

[18] S. Kaur, M. Ganapathy, and G. K. Sidhu, "Designing learning elements using the multiliteracies approach in an ESL writing classroom," 3L: The Southeast Asian Journal of English Language Studies, vol. 18(3), pp. 119-134, 2012.

[19] E. Howell, D. Reinking, and R. Kaminski, "Writing as creative design: Constructing multimodal arguments in a multiliteracies framework," Journal of Literacy and Technology, vol. 16(1), pp. 2-35, 2015.

[20] J. T. Grabill and T. Hicks, "Multiliteracies meet methods: The case for digital writing in English education," English Education, vol. 37(4), pp. 301-311, 2005.

[21] F. Dafit, "Pengaruh model pembelajaran multiliterasi terhadap kemampuan membaca siswa sekolah dasar," Jurnal Inovasi Pendidikan dan Pembelajaran Sekolah Dasar, vol. 1(1), pp. 87-100, July 2017.

[22] J. W. Creswell, Research design qualitative, quantitative, and mixed methods approaches ( $2^{\text {nd }}$ Ed.). California, USA: Sage Publication, Inc, 2003.

[23] J. W. Creswell, Research design qualitative, quantitative, and mixed methods approaches ( $4^{\text {th }}$ Ed.).California, USA: Sage Publication, Inc., 2014.

[24] C. T. Rosidah, "Pengaruh pembelajaran berbasis multiliterasi terhadap kemampuan berpikir kritis," Jurnal PINUS, vol. 4(1), pp. 38-43, 2018.

[25] E. Untari, "Pentingnya pembelajaran multiliterasi untuk mahasiswa Pendidikan Guru Sekolah Dasar dalam mempersiapkan diri menghadapi Kurikulum 13," Wahana Sekolah Dasar (Kajian Teori dan Praktik Pendidikan), vol 25(1), pp. 16-21, January 2017.

[26] S. V. Susilo and G. R. Garnisya, "Penerapan model multiliterasi untuk meningkatkan kemampuan membaca pemahaman siswa sekolah dasar," Jurnal Cakrawala Pendas, vol. 4(2), pp. 66-71, July 2018.

[27] F. Dafit, "Implementasi model multiliterasi pada proses pembelajaran membaca pemahaman siswa kelas IV sekolah dasar," Jurnal Sekolah (JS), vol. 1(2), pp. 53-59, March 2017.

[28] I. Noviyanti, L. Lenovia, N. Siti, and W. N. Elsa, "Makalah konsep pembelajaran multiliterasi," retrieved from https://lenovialola.wordpress.com/2017/01/14/makalah-konseppembelajaran-multiliterasi/ 